\title{
Adoption of Internet-enabled Supply Chain Integration: Institutional and Cultural Perspectives
}

\author{
Hefu Liu \\ School of Management \\ University of Science and Technology of China, China \\ liuhf@mail.ustc.edu.cn \\ Weiling Ke \\ School of Business \\ Clarkson University, USA \\ wke@clarkson.edu \\ Kwok Kee Wei \\ College of Business \\ City University of Hong Kong, Hong Kong \\ isweikk@cityu.edu.hk \\ Jibao Gu \\ School of Management \\ University of Science and Technology of China, China \\ iibao@ustc.edu.cn \\ Huaping Chen \\ School of Management \\ University of Science and Technology of China, China \\ hpchen@ustc.edu.cn
}

\begin{abstract}
Fostering supply chain integration (SCl) via Internet technologies has been widely regarded as a critical factor for firm success. Internet-enabled SCI may help enhance firms' capabilities in technology, product and market development, and thus allows firms to initiate or adapt to competitive changes in the market. Yet, the decision on Internet-enabled SCl is challenging due to the high uncertainties involved. Research on the antecedents of Internet-enabled SCl is of interest to both researchers and practitioners. Based on the view of upper echelons theory (UET), this research derives a syncretic model for firms' adoption of Internet-enabled SCI by presenting senior executives' cognitions as firms' perceived institutional pressures, and senior executives' values as firms' organizational culture. Results from a survey show that institutional pressures and a culture that values organic process have a strong impact on firms' inclination toward Internet-enabled SCl. In addition, we find that institutional pressures and organizational culture have interaction effects on Internet-enabled SCl.
\end{abstract}

Keywords: Internet-enabled supply chain integration, Institutional pressures, Organizational culture, Upper echelons. 


\section{Introduction}

Fostering Supply Chain Integration (SCl) via Internet technologies would help firms improve firm competitiveness (Barney, 2007; Kandemir et al., 2006; Ke et al., 2009; Kim et al., 2006; Liu et al., 2010; Patnayakuni et al., 2006; Rai et al., 2006). The globalization of markets, short product life cycles, and increased complexity of products are forcing firms to compete as groups or chains, instead of individually (Kandemir et al., 2006). Meanwhile, the diffusion of Internet technologies is reconstructing the supply chain, which enables firms to streamline and integrate the supply chain with a more applicable and easier to implement format (Frohlich, 2002; Zhu et al., 2006). As such, Internet-enabled SCl is becoming an efficient collaboration mechanism which helps firms meet current market requirements.

However, developing Internet-enabled $\mathrm{SCl}$ is a challenge for many firms because of the uncertainties related to network effects and interdependence in channel process (Liu et al., 2010; Olson and Boyer, 2003; Teo et al., 2003; Zhu et al., 2006). Given the prevalence of the e-business nowadays, the lack of supply chain integration may cause critical failure of the supply chain and erode firms' competitive position (Liu et al., 2010). As such, research investigating how firms weigh the potential benefits and uncertainties involved in supply chain integration is of great significance and interest. Unfortunately, our understanding of the antecedents of $\mathrm{SCl}$ is still limited (Liu et al., 2010; Zhao et al., 2008).

A recent literature review indicates that scholars increasingly tout institutional theory as an important perspective for studies on interorganizational systems (IOS) adoption (e.g., Grewal and Dharwadkar, 2002; Ke et al., 2009; Liu et al., 2010; Son and Benbasat, 2007; Teo et al., 2003). This theory proposes that institutional pressures, emanating from the institutional environment and transmitted through the network, can act as the critical market factors affecting a firm's predisposition toward innovation adoption. However, the findings of previous institutional studies have been mixed. While some studies found the significant influence of a firm's perceived institutional factors, others showed that it was insignificant (e.g., Khalifa and Davison, 2006; Liang et al., 2007; Son and Benbasat, 2007; Teo et al., 2003). Thus, exploring the potential firm-level factors, as such cultural factors investigated in the current paper, may help to explain why firms in the same institutional environment have different inclination toward Internet-enabled SCl.

It is well established that cultural factors as one type of firm-level factors could impact the firm's uncertainty perception and values of inter-firm relationships (e.g., Kappos and Rivard, 2008; Leidner and Kayworth, 2006; Leisen et al., 2002; Ruppel and Harrington, 2001). This implies that cultural factors, similar to institutional factors, may affect firm intention to adopt innovations. As such, an empirical research investigating these factors in a single framework may extend our understanding of the antecedents of Internetenabled SCl.

In this research, we aim to relate both institutional theories and organizational culture theories to Internet-enabled SCI. Specifically, we begin with upper echelons theory (UET) in which senior executives are taken as in the critical agent making firm decisions (Chen and Hambrick, 1995). According to UET, a firm's strategic choices are made on the basis of its senior executives' personalized construal of the situations (Chen and Hambrick, 1995). Senior executives' cognitions and values are strong predictors of firm strategic choices. Building on this thesis, we extend the UET to the context of Internet-enabled $\mathrm{SCl}$ by presenting senior executives' cognitions as their perception of institutional pressures, and senior executives' values as firms' organizational culture. In particular, we propose that Internet-enabled $\mathrm{SCl}$ is driven by a firm's perceived institutional pressures which are reflected by its senior executives' cognitions and the firm's organizational culture which is indicated by its senior executives' values. Against this background, we conduct the research in the context of firms' intention to adopt electronic supply chain management 
(eSCM) systems, which are Internet-based IOS that allow firms to jointly orchestrate their supply chain operations (Chwelos et al., 2001; Subramani, 2004).

\section{Literature Review}

\section{The View of Upper Echelons Theory}

Upper echelons theory (UET) suggests the critical role of senior executives in firm strategic choices (Carpenter et al., 2004; Chen and Hambrick, 1995; Finkelstein and Hambrick, 1996). This theory provides a theoretical foundation for understanding firm strategic decisions on the adoption of organizational innovations. According to UET, a firm's strategic choices can be strongly predicted by its senior executives' cognitions and values (Chen and Hambrick, 1995; Finkelstein and Hambrick, 1996). Specifically, UET suggests that senior executives' cognitions are reflected by their knowledge of future events, alternatives and their consequences. In contrast, their values are reflected by their "principles for ordering consequences or alternatives according to preference." (Chen and Hambrick, 1995, p. 195)

Due to the difficulties to measure senior executives' cognitions and values directly, UET researchers have been using senior executives' demographic characteristics as surrogates for executives' cognitions and values (Chen and Hambrick, 1995). While this approach helps scholars unveil the antecedents of a firm's strategic decision making, demographic characteristics per se are unlikely to impact its strategic choices (Carpenter et al., 2004). They are just "used to proxy larger, complex and hard-to-get-at constructs" (Carpenter et al., 2004, p. 771), such as cognitions and values. Senior executives rely on their personalized construal of the situations they face when making strategic decisions (Chen and Hambrick, 1995). To investigate how cognitions and values affect executives' strategic choices, it is appropriate to focus on factors that can directly reflect executives' construal of the situations.

In line with UET, we propose that Internetenabled $\mathrm{SCl}$ is a firm's strategic choice that reflects its senior executives' cognitions and values. In the view that Internet-enabled SCI involves not only benefits, but also uncertainties and risks, and its results turn out to be highly unpredictable (Barney, 2007), senior executives will adopt some external referents to extend their cognitions to justify their decisions. According to institutional theory, senior executives' cognitions of institutional prescriptions and norms, coined institutional pressures, are an example of such external decision referents (DiMaggio and Powell, 1983). Indeed, cognitions about the institutional environment have been widely proposed as significant factors affecting firm strategic choices in existing IS research (e.g., Ke et al., 2009; Khalifa and Davison, 2006; Teo et al., 2003).

On the other hand, executives' values determine their attitudes toward and principles for strategies choice (Chen and Hambrick, 1995). Senior executives usually maintain a wide array of values, such as religious belief, trust and commitment. However, shared values embedded in the organizational culture are the most influential in affecting executives' firm-level strategic decision making. Organizational culture provides executives with guidelines for managing relationships with constituencies in the institutional environment including their channel partners (McAfee et al. 2002; Mentzer et al. 2000; Mello and Stank 2005). Indeed, organizational culture has been measured as a surrogate for executives' values in the extant literature (Berthon et al., 2001; Deshpandé et al., 1993; Khazanchi et al., 2007). Therefore, based on UET, institutional theory, the competing values model and the extant IS research, we submit that executives' perceptions of institutional pressures and organizational culture are appropriate surrogates for their cognitions and values, respectively, and affect their decision on Internet-enabled SCI simultaneously.

\section{Research Framework}

\section{Institutional Pressures and Internet- enabled Supply Chain Integration}

In the view of institutional theory, the institutional environment provides rule-like expecta- 
Adoption of Internet-enabled Supply Chain Integration: Institutional and Cultural Perspectives / Liu et al.

tions and norms for appropriate organizational structures, behaviors, and practices (DiMaggio and Powell, 1983; Scott, 1995). Conforming to such rule-like expectations and norms would help firms maintain their legitimacy and secure access to scarce resources. Further, the firm's perceived institutional expectations and norms would be transformed into senior executives' cognitions about the alternatives and consequences of the related strategic move (DiMaggio and Powell, 1983; Scott, 1995). Specifically, senior executives assimilate the information on these expectations and norms, and make the information become parts of their cognitions, apply the information as referents to appraise the potential benefits and risks of adopting this strategic practice, and then position their firm to hedge against uncertainties accordingly (Choi and Eboch, 1998; Zsidisin et al., 2005).

DiMaggio and Powell (1983) have defined the pressures that emanated from the institutional environment and push firms to adopt shared notions and routines as "institutional pressures", and call such prevalent adoption as "isomorphism." To analyze why firms adopt similar practices, they further categorize institutional pressures into normative, coercive, and mimetic pressures. When firms perceive these pressures, such perceptions would be embedded in senior executives' cognitive map and reflect their knowledge about the environment (DiMaggio and Powell, 1983; Grewal and Dharwadkar, 2002). As UET proposed, such cognitions would impact firms' strategic choices, such as their choices of inter-organizational relationships, and specific channel structures and processes.

\section{Normative pressures}

Normative pressures refer to the pressures that primarily resulted from expectations regarding how work should be conducted professionally (DiMaggio and Powell, 1983). These expectations are transferred through inter-organizational channels and gradually become shared norms. The shared norms are usually latent and informal. They can embedded in senior executives' cognitive map, and then reflect their cognitions about the rules of the market and their relationship network. Furthermore, these shared norms are concerned with firms' procedural legitimacy. Thus, in a supply chain, a firm's strategic choices would be significantly impacted by the shared norms.

Scholars propose that socially accepted norms could generate normative pressures on firms to induce them to regenerate or adopt new patterns within their channels (Ke et al., 2009; Teo et al., 2003). For example, the prevalence/extent of a practice in the market creates and strengthens norms, which in turn, influences firms' choices. In the Internet-enabled $\mathrm{SCl}$ context, normative pressures could increase as such integration becomes prevalent. A firm's perceived normative pressures reflect its senior executives' cognitions about the integration, and then help them formulate attitudes toward such integration. To avoid being locked out of cooperative relationships, senior executives will choose to conform to such pressures and adopt Internet-enabled SCl.

H1: The greater the executives' perceived normative pressures toward Internet-enabled $\mathrm{SCl}$, the greater the likelihood that the firm will adopt Internet-enabled SCI.

\section{Mimetic pressures}

Mimetic pressures mainly stem from firms' perceived success of competitors' actions (DiMaggio and Powell, 1983). Such perceptions can reflect senior executives' cognitions about the environment of competition and their firms' competitive status directly. According to Dickson (1992), studying how admired competitors make decisions could extend executives' cognitions about the market, and thus lead to firms reducing the uncertainty by imitating those admired competitors' planning procedures. Such imitation helps firms reduce their perceived risk. Thus, although imitation is not always clearly justifiable by efficiency considerations (Ottesen and Gronhaug, 2002), firms may still conduct imitation to pursue status-conferring legitimacy or approval from powerful external bodies (Grewal and Dharwadkar, 2002; Ke et al., 2009). 
Different from normative pressures, which stem from the prevalence of firms' actions, mimetic pressures mainly originate from the perceived success of competitors' actions. They reflect senior executives' cognitions about the difference of competitive advantages between their firms and their competitors. Therefore, once a firm sees the benefits (such as, economic benefits or legitimacy gaining) and the low risk of copying competitors' successful actions, mimetic isomorphism will occur (Ke et al., 2009; Teo et al., 2003). Being aware of the great benefits of Internetenabled $\mathrm{SCl}$ gained by their competitors, such as the reduction of costs and performance improvement, firms would consciously or unconsciously imitate such successful practices.

H2: The greater the executives' perceived mimetic pressures toward Internet-enabled $\mathrm{SCl}$, the greater the likelihood that the firm will adopt Internet-enabled SCI.

\section{Coercive pressures}

Coercive pressures refer to the pressures stemming from political influences exerted by the powerful firms that the focal firm depends on (DiMaggio and Powell, 1983; Teo et al., 2003). They are common in the institutional environment and can operate through relational channels among members of a network (Ke et al., 2009; Teo et al., 2003). In essence, coercive pressures reflect senior executives' cognitions about the asymmetry of power between their firms and their partners.

Generally, when a powerful firm perceives that other channel members' actions are in conflict with its expectations, it would exercise a coercive strategy to demand partners adopt its favorable structures or practices in order to serve its own interest (Moore et al., 2004). Partners that depend on the powerful firm may comply with such demand to secure their market status and access to scarce resources due to the asymmetry of power (Ke et al., 2009; Kim, 2000). In the case of Internet-enabled $\mathrm{SCl}$, when a dominant channel member favors this integration, and coercively pushes partners to join it, the dependent firms would perceive coercive pressures.
Such pressures further extend the dependent firms' senior executives' cognitions about the asymmetry of power between them and the partner. To secure their survival, they would be likely to comply with the dominant partner's requests for Internet-enabled SCI.

H3: The greater the executives' perceived coercive pressures toward Internet-enabled $\mathrm{SCl}$, the greater the likelihood that the firm will adopt Internet-enabled SCI.

\section{Organizational Culture and Internet- enabled Supply Chain Integration}

Organizational culture is a system of collectively conscious and unconscious assumptions, values and beliefs (McDermott and Stock, 1999). It indicates senior executives' values of external events and can critically impact firm operations (Kappos and Rivard, 2008; Khazanchi et al., 2007; Leidner and Kayworth, 2006; Quinn and Rohrbaugh, 1983; Zammuto and O'Connor, 1992). In particular, executives' perception of organizational culture influences the way they interpret and respond to external events (Deshpandé et al., 1993). Thus, the effects of organizational culture can be found in the ends firms seek and the means they use to attain these ends (Zammuto and O'Connor 1992).

Given that a firm may have multiple organizational subcultures, in addition to the dominant culture, this study adopts the Competing Values Model (CVM) to study organizational culture. The CVM reveals the complexity of choices facing executives and the congruence of concerns across firms (Buenger et al., 1996). According to Howard (1998), the CVM allows scholars examine the complexity of culture and compare organizational culture within and between firms, firms' subgroups, and even individuals. It helps executives understand the values underlying their organizational culture and adapt their firm to reach desired outcomes (Howard, 1998). More importantly, the CVM provides a quantitative way to study organizational culture, while cultural orientation has been proposed to be applied to qualitative research (e.g., Khazanchi et al., 2007; McAfee et al., 2002; Mentzer et al., 2000) 


\section{Organic Processes (flexibility, spontaneity)}

\begin{tabular}{|c|c|}
\hline$\underline{\text { Clan }}$ & Adhocracy \\
\hline $\begin{array}{l}\text { Means: } \\
\text { Cohesion; morale } \\
\text { Ends: } \\
\quad \text { Human resource development }\end{array}$ & $\begin{array}{l}\text { Means: } \\
\text { Flexibility; readiness } \\
\text { Ends: } \\
\text { Growth; resource acquisition }\end{array}$ \\
\hline $\begin{array}{c}\text { Internal Focus } \\
\text { (smoothing activities, alliance) }\end{array}$ & $\begin{array}{c}\text { External Focus } \\
\text { (competition, differentiation) }\end{array}$ \\
\hline $\begin{array}{l}\text { Means: } \\
\text { Information management; } \\
\text { communication }\end{array}$ & $\begin{array}{l}\text { Means: } \\
\text { Planning; goal setting }\end{array}$ \\
\hline $\begin{array}{l}\text { End: } \\
\text { Stability; control }\end{array}$ & $\begin{array}{l}\text { Ends } \\
\text { Productivity; efficiency }\end{array}$ \\
\hline Hierarchy & Market \\
\hline \multicolumn{2}{|c|}{ Mechanistic Processes (control, order, stability) } \\
\hline NOTE: ${ }^{a}$ Adapted from Quinn (1988) anc & eshpandé et al (1993) \\
\hline
\end{tabular}

The CVM categorizes organizational culture into clan, adhocracy, hierarchy and market (Quinn and Rohrbaugh, 1983). As shown in Figure 1, these culture types are determined by two important dimensions. The vertical axis represents cultures from organic to mechanistic, i.e., organic culture focuses on flexibility and spontaneity while mechanistic culture emphasizes control and stability. The abscissa axis describes internal and external focus, i.e., internal focus emphasizes smoothing activities and alliances, and external focus stresses competition and environmental differentiation. Further, Deshpandé et al., (1993) note that these four culture types are coexistent with one being dominant, rather than being mutually exclusive. It indicates that a firm might has a high rating on one culture when it has other cultures simultaneously. By acknowledging the co-existence of multiple value systems, with one being dominant, the CVM aids the understanding of the conflicts or competing values of organizational life (Khazanchi et al., 2007).

\section{Clan culture}

A clan culture has an internal focus and values organic processes. It emphasizes cohesiveness, participation, and teamwork (Deshpandé et al., 1993). According to Brown and Starkey (1994), senior executives in firms with a clan culture normally value communication and cooperation internally and highly favor collaborative communications. Such values facilitate the development of inter-firm trust, cooperation and long-term commitment in firms' channels (Leisen et al., 2002; White et al., 2003). Thus, collaborative communication among integrated partners is consistent with the values of a clan culture. In addition, Internet-enabled SCl aims to promote market information transmission, and therefore, it fits the managerial values of a clan culture (Chi et al., 2007). 
A clan culture also values flexibility, adaptation and market responsiveness. It is low in conflict and resistance to change (Moorman, 1995). White et al. (2003) note that senior executives in this culture are inclined to perceive that they can control the outcomes of an uncertain market environment. Although Internet-enabled $\mathrm{SCl}$ may incur some opportunistic behaviors and instabilities, it is still an efficient structure to enhance competitive advantage (Kandemir et al., 2006; Webster, 1992). It can create values that firms cannot achieve individually (Frohlich, 2002). Thus, a clan culture is likely to view risk taking as a good strategic choice (White et al., 2003), and therefore firms with this culture would tend to adopt Internet-enabled SCl:

H4: The higher its clan culture, the greater the likelihood that a firm will adopt Internetenabled SCl.

\section{Adhocracy culture}

An adhocracy culture has an external focus and emphasizes organic processes. It is characterized by environmental scanning and change assumption (Deshpandé et al., 1993). This culture views that the environment is complex, turbulent, politicized, and can play as a significant factor in firms' survival. Senior executives in this culture value the finding of new markets and directions for growth, and take such finding as the main criteria for firms' effectiveness (Deshpandé et al., 1993). With an external focus and the goal of acquiring resources, firms make decisions based on external performance benchmarks and whether they meet external stakeholders' requests (Deshpandé et al., 1993; Detert et al., 2000). Thus, an adhocracy culture tends to maintain congruence with a changing environment and encourage entrepreneurship, creativity, and risk taking (Leisen et al., 2002).

Kandemir et al. (2006) conclude that interfirm collaboration enhances firms' agility and responsiveness to market changes, ranging from customer demand to resource shortages. It provides firms with a chance of growth. Therefore, an adhocracy culture would make firms tend to adopt Internet-enabled SCI. This inclination is boosted by senior executives' risk-taking values (Deshpandé et al., 1993) and experimentation- encouraging behavior in these firms (Berthon et al., 2001), despite the fact that Internet-enabled $\mathrm{SCl}$ is associated with opportunistic behaviors and instabilities. Hence, an adhocracy culture would support a firm's adoption of Internet-enabled $\mathrm{SCl}$ :

H5: The higher its adhocracy culture, the greater the likelihood that a firm will adopt Internet-enabled SCI.

\section{Hierarchy culture}

A hierarchy culture is characterized by an emphasis on mechanistic processes and internal focus. It assumes that a firm's excellence is due to internal operations rather than the external environment (Detert et al., 2000). In this culture, senior executives normally value internal organizing and structuring, and take them as the critical factors for their mission accomplishment (Buenger et al., 1996). They seldom value innovations, especially the innovations that allow for a quick response to an uncertain environment and imperfect market (Chi et al., 2007).

A hierarchy culture is more concerned about order, rules, and regulations (Deshpandé et al., 1993), and tends to be conservative and cautious (Ruppel and Harrington, 2001). Senior executives in this culture thus value control and security, and distrust changes (Leisen et al., 2002). Changing existing channel structures is a big challenge for a hierarchy culture. Quinn and Rohrbaugh (1983) propose that to maintain stability, a hierarchy culture is inclined to stress formal internal content management, such as the management of measurement, documentation, and information. It does not support the transmission of market information across firms in a channel (Chi et al., 2007). Therefore, firms with a hierarchy culture would be unlikely to engage in Internet-enabled $\mathrm{SCl}$ because of these opportunistic behaviors, instabilities and the required information sharing (Kandemir et al., 2006). 


\begin{tabular}{|c|c|c|c|}
\hline Organization Demography & Category & $\begin{array}{l}\text { Frequency } \\
(n=134)\end{array}$ & Percent \\
\hline \multirow{2}{*}{ Industry } & Manufacturing & 62 & $46.27 \%$ \\
\hline & Services & 72 & $53.73 \%$ \\
\hline \multirow{4}{*}{$\begin{array}{l}\text { Number of } \\
\text { Employees }\end{array}$} & $\leq 100$ & 35 & $26.12 \%$ \\
\hline & $101-500$ & 33 & $24.63 \%$ \\
\hline & $501-1000$ & 19 & $14.18 \%$ \\
\hline & More than 1000 & 47 & $35.07 \%$ \\
\hline \multirow{4}{*}{ Number of IT Employees } & $\leq 5$ & 54 & $40.30 \%$ \\
\hline & $6-10$ & 25 & $18.70 \%$ \\
\hline & $11-15$ & 13 & $9.70 \%$ \\
\hline & More than 15 & 42 & $31.30 \%$ \\
\hline
\end{tabular}

H6: The lower its hierarchy culture, the greater the likelihood that a firm will adopt Internetenabled SCl.

\section{Market culture}

A market culture emphasizes mechanistic processes and external focus. It is marketoriented and stresses competitive advantage and market superiority (Leisen et al., 2002). In this culture, senior executives value productivity achievement, and take it as a key measure of effectiveness (Deshpandé et al., 1993). Therefore, firms with a market culture are apt to make all decisions based on rational-economic criteria (Ruppel and Harrington, 2001), and make profit maximization as their primary goal.

Moreover, to improve performance, a market culture favors acquiring market information. In the case of Internet-enabled SCl, this integration can help firms minimize transaction cost and maximize long-term competitive position (Rindfleisch and Moorman, 2003). The sharing of resources and market information enables firms to expand joint capabilities (Johnson, 1999; Kandemir et al., 2006). These potential benefits of Internet-enabled $\mathrm{SCl}$ are attractive to a market culture. In addition, a market culture favors inter-firm coordination due to its low tolerance for market uncertainties (Detert et al., 2000). Given that the primary purpose of Internet-enabled $\mathrm{SCl}$ is to reduce environmental uncertainties and market imperfection (Kandemir et al., 2006), it fits well with the managerial objective of a market culture.
H7: The higher its market culture, the greater the likelihood that a firm will adopt Internetenabled SCl.

\section{Research Method}

\section{Sample and Data Collection}

We conducted a survey to test our hypotheses. Firms operating in manufacturing and services industries in China were chosen as our samples. China has become an economic powerhouse and firms operating in China are significant players in international supply chain. We obtained a list of senior executives from an institution which was famous for its executive training programs. From this list, we identified 202 executives. No two executives were from the same firm. These executives met our sample requirement for three aspects. First, they had taken supply chain management courses, thus they had the knowledge background of Internet-enabled $\mathrm{SCl}$ in general, and eSCM in particular. Second, as executives of organizations, they knew their organizational culture and had direct contact with the organization's partners. Third, most of them made practical decisions on the behalf of their organizations in the real world. The institution helped us send out the questionnaires, and make follow-up calls and send emails to encourage response.

Finally, we received 151 questionnaires, including 17 incomplete questionnaires which were discarded. Thus, we obtained 134 useful questionnaires and a response rate of approximately $66 \%$. The demography of these 
samples was shown in Table 1. Further, we tested the possible non-response bias by Armstrong and Overton's (1977) method. Through comparing the chi-squares of the responses from the first $25 \%$ of the respondents to that of the final $25 \%$, we found that there were no significant differences between these two groups on key measures. This indicates that non-response bias is not an issue for this study.

\section{Measures}

Given the digital features of current supply chain management, scholars increasingly regard the adoption of IOS as the initiative of $\mathrm{SCl}$ and indicate that the application of Internet-based IOS are bringing $\mathrm{SCl}$ into the new Internet-enabled SCl era (Boyer and Olson, 2002; Frohlich, 2002; Frohlich and Westbrook, 2002; Lee and Whang, 2004; Rai et al., 2006). It is suggested that these systems allow a firm to achieve efficient flows of products, services, information and capital with a more applicable and easier to implement format (Frohlich, 2002; Zhu et al., 2006). In this view, we chose one type of Internet-enabled IOS, electronic Supply Chain Management (eSCM) systems, as our research object. eSCM reflect the technical enabler of the orchestration of value chain operations across organizational boundaries (Chwelos et al., 2001; Subramani, 2004). Many scholars and practitioners have treated ESCM, such as SAP, Oracle and IBM e-business as powerful strategic weapons for supply chain management (Frohlich, 2002; Gunasekaran et al., 2002; Ke et al., 2009). As an innovative IOS, a lot of firms are in the middle of making their decisions on adopting eSCM to promote Internetenabled SCl. Thus, given the essential role of Internet technologies in $\mathrm{SCl}$, measuring a firm's intention to adopt eSCM is an appropriate way to evaluate its intention to be engaged in Internet-enabled SCl.

The measurement items of our questionnaire were adapted from existing and well-tested scales offered by the extant literatures, as appendix shows. These scales have been proved to have good validity and reliability. In the questionnaire, all items were measured with 7-point Likert scales, ranging from "strongly disagree" to "strongly agree." We assessed a firm's Internet-enabled SCl decision using three items related to the firms' intention of adopting eSCM. These items were adapted from Teo et al. (2003) and Khalifa and Davison (2006). To make sure respondents have the same understanding of eSCM as the authors, we provided a clear description of eSCM in the questionnaire. We measured the organizational culture using twelve items from Yeung, Brockbank and UIrich (1991) and Deshpandé et al. (1993), with three items for each organizational culture type.

To measure a firm's perceived institutional pressures, we adapted the scales from Teo et al. (2003) and Khalifa and Davison (2006). Normative pressures were measured by three items on the extent of eSCM adoption by suppliers, customers and competitors in the focal firm's industry; mimetic pressures were measured by three items on the perceived success of the firm's competitors who had adopted eSCM; coercive pressures were measured by four items on the perceived dominance of supplier adopters and customer adopters.

With these items, we developed an English questionnaire and then translated it into Chinese. We hired a professional translator who knew nothing about our study to translate the Chinese questionnaire back to English. No semantic discrepancies were found when we compared the translated English questionnaire with the original English version, which suggested that the Chinese questionnaire was equivalent to the English one. All instrument items are provided in the appendix.

\section{Analysis and Results}

\section{Common method bias}

Using the Harman's one-factor test on all measurement items (Podsakoff et al., 2003), we tested the possible common method bias. The principal components factor analysis yielded five factors with eigenvalues greater than 1.0 and accounted for $66.51 \%$ variance. The majority of the variance was on $17.57 \%$. 
Adoption of Internet-enabled Supply Chain Integration: Institutional and Cultural Perspectives / Liu et al.

This indicated that common method bias was not a serious concern in this study.

\section{Validity and Reliability}

In this paper, the validity of the items was assessed for content validity and construct (convergent and discriminant) validity. A measure could be said to possess content validity if the items were selected and refined through an extensive process based on a literature review. As previously discussed, our instrument's content validity was established via the conventional process for measures chosen.

Convergent and discriminant validities were assessed to confirm the validity of measures through confirmatory factor analysis (CFA). Cronbach alphas, composite reliability of constructs, and average variance extracted (AVE) were used to test convergent validity.
As shown in Table 2, Cronbach alphas ranged from 0.794 to 0.883 , which exceeded the benchmark of 0.70 ; composite reliability ranged from 0.867 to 0.928 and above the 0.70 recommended level; and AVE scores for every construct ranged from 0.669 to 0.811 and above the 0.50 recommended level. Thus, our measure's convergent validity was suggested by these criteria. Furthermore, we tested discriminant validity by comparing the relationship between correlations among constructs and the square root of AVEs. In Table 3 , the square roots of the focal constructs' AVEs were higher than the correlations between different constructs, which confirmed the discriminant validity. Also, we employed a Chi-square test to further assess the discriminant validity. The results also confirmed the discriminant validity of our measurement model.

\section{Table 2 - Results of Confirmatory Factor Analysis}

\begin{tabular}{|l|l|l|l|l|}
\hline & Items & Cronbach's Alpha & Composite Reliability & AVE \\
\hline Clan Culture (CC) & 3 & 0.805 & 0.883 & 0.717 \\
\hline Adhocracy Culture (AC) & 3 & 0.806 & 0.885 & 0.721 \\
\hline Hierarchy Culture (HC) & 3 & 0.794 & 0.867 & 0.688 \\
\hline Market Culture (MC) & 3 & 0.839 & 0.868 & 0.692 \\
\hline Normative Pressures (NP) & 3 & 0.841 & 0.904 & 0.759 \\
\hline Mimetic Pressures (MP) & 3 & 0.801 & 0.883 & 0.716 \\
\hline Coercive Pressures (CP) & 4 & 0.835 & 0.890 & 0.669 \\
\hline Adoption Intention (Al) & 3 & 0.883 & 0.928 & 0.811 \\
\hline
\end{tabular}

NOTE: AVE= Average Variance Extracted

\section{Table 3 - Inter-Construct Correlations: Consistency and Reliability Tests}

\begin{tabular}{|l|l|l|l|l|l|l|l|l|}
\hline & CC & AC & HC & MC & CP & MP & NP & Al \\
\hline Clan Culture (CC) & $\mathbf{0 . 8 4 9}$ & & & & & & & \\
\hline Adhocracy Culture (AC) & 0.733 & $\mathbf{0 . 8 4 7}$ & & & & & & \\
\hline Hierarchy Culture (HC) & 0.469 & 0.419 & $\mathbf{0 . 8 2 9}$ & & & & & \\
\hline Market Culture (MC) & 0.476 & 0.408 & 0.545 & $\mathbf{0 . 8 3 2}$ & & & & \\
\hline Coercive Pressures (CP) & 0.260 & 0.380 & 0.324 & 0.131 & $\mathbf{0 . 8 1 8}$ & & & \\
\hline Mimetic Pressures (MP) & 0.212 & 0.236 & 0.293 & 0.104 & 0.771 & $\mathbf{0 . 8 4 6}$ & & \\
\hline Normative Pressures (NP) & 0.196 & 0.245 & 0.226 & 0.063 & 0.563 & 0.574 & $\mathbf{0 . 8 7 1}$ & \\
\hline Adoption Intention (AI) & 0.200 & 0.289 & 0.226 & 0.118 & 0.528 & 0.436 & 0.508 & $\mathbf{0 . 9 0 1}$ \\
\hline
\end{tabular}

NOTE: The shaded numbers in the diagonal row are square roots of the AVE 


\section{Discriminant Analysis}

In this research, organizational culture was divided into four independent factors based on two dimensions - each consisting of two independent factors. Thus, to avoid interaction effects among those culture-related factors and to identify the differences of the role of those four types of culture clearly, we conducted a two-group discriminant analysis following Deshpandé et al. (1993). Discriminant analysis is an appropriate technique to distinguish each factor's contribution to a linear function that could discriminate best between prior defined groups (Hair et al., 1998). In our study, the respondents' overall adoption intention evaluation was used to divide respondents into groups of high adoption intention and low adoption intention. To classify firms according to their adoption intention, cluster analysis was utilized (Hair et al., 1998). Through quick cluster, we placed 56 firms in the "high" adoption group and 78 firms in the "low" adoption group.

To assess the accuracies of the classification, we used the proportional chance criterion (Cpro) on the basis of Morrison's (1969) suggestions. Generally, Cpro equated to p2 plus (1-p) 2 where $p$ was the proportion of samples in the first group. As shown in Table 4, the classification ability of the discriminant model was $69.40 \%$. It indicates that our dis- criminant model has an accuracy rate of $69.4 \%$ in placing respondents into either high adoption group or low adoption group. Comparing this accuracy rate to the proportional chance criterion, $51.35 \%$, we can state that the classification has reasonable predictive ability. Press's $Q$ statistics for the model was 20.33, ex-ceeding the critical value of 6.63 $(p=0.05)$ (Hair, Anderson, Tatham and Black 1998). Thus, the classification accuracy for the analysis exceeded a statistically significant level expected by chance, and the discriminant model is valid.

In our discriminant analysis, the main intention was to show major differences between the high adoption group and low adoption group at each factor level. We present group means and standard deviations for the independent variables in Table 5 . As the table shows, the means of these salient factors influencing firms' adoption of $\mathrm{SCl}$ were higher for the high adoption group than those of the low adoption group. In addition, higher standard deviation for the high adoption group (except clan culture) indicated larger dispersion. These results indicate that for firms with different level of intention to adopt eSCM, their perceived institutional pressures and organizational culture would be different. It could help us understand the different degree of senior executives' perceived pressures and cultures in the two separate groups.

\section{Table 4 - Classification Results}

\begin{tabular}{|c|c|c|c|c|c|c|}
\hline \multirow{2}{*}{ Group } & \multicolumn{2}{|l|}{ Predicted Count } & \multirow{2}{*}{ Total } & \multicolumn{3}{|c|}{ Accuracy } \\
\hline & 1: High allying (56) & 2: Low allying (78) & & Overall & $\mathrm{C}_{\text {pro }}{ }^{\mathrm{a}}$ & Press's $Q^{b}$ \\
\hline 1 (High) & $\begin{array}{l}38 \\
67.9 \% \\
\end{array}$ & $\begin{array}{l}18 \\
32.1 \% \\
\end{array}$ & \begin{tabular}{|l|}
56 \\
$100 \%$ \\
\end{tabular} & \multirow{2}{*}{$69.40 \%$} & \multirow{2}{*}{$51.35 \%$} & \multirow{2}{*}{20.33} \\
\hline 2 (Low) & \begin{tabular}{|l|}
23 \\
$29.50 \%$
\end{tabular} & $\begin{array}{l}55 \\
70.50 \%\end{array}$ & $\begin{array}{l}78 \\
100 \%\end{array}$ & & & \\
\hline
\end{tabular}

NOTE: a. $\mathrm{C}_{\mathrm{pro}}=$ proportional chance criterion.

$C_{\text {pro }}=p^{2}+(1-p)^{2}$ where $p$ is the proportion of samples in the first group.

b. Press's Q: A measure to determine the significance of the classification accuracy is better than chance

$$
\begin{aligned}
& Q=\left[N-\left(n^{*} g\right)\right]^{2} /[N-(g-1)](Q \text { is chi-square distributed for } d f=1) \\
& \text { Where } \\
& N=\text { total number of subjects } \\
& n=\text { number of cases correctly classified } \\
& g=\text { number of groups }
\end{aligned}
$$




\begin{tabular}{|c|c|c|c|c|}
\hline \multirow{2}{*}{ Variables } & \multicolumn{2}{|l|}{ Mean } & \multicolumn{2}{|c|}{ Standard Deviation } \\
\hline & High adoption & Low adoption & High adoption & Low adoption \\
\hline Normative & 4.424 & 3.532 & 1.224 & 1.199 \\
\hline Mimetic & 3.842 & 3.094 & 1.103 & 0.835 \\
\hline Coercive & 4.153 & 3.122 & 1.138 & 0.853 \\
\hline Clan & 3.798 & 3.325 & 1.305 & 1.326 \\
\hline Adhocracy & 3.995 & 3.263 & 1.393 & 1.217 \\
\hline Hierarchy & 3.465 & 3.100 & 1.448 & 1.083 \\
\hline Market & 3.158 & 2.936 & 1.226 & 1.091 \\
\hline
\end{tabular}

\begin{tabular}{|c|c|c|c|c|}
\hline Variables & Wilks' Lambda & $\begin{array}{l}\text { Discriminant } \\
\text { Loadings }\end{array}$ & F-tests & Significance \\
\hline Normative & 0.866 & 0.694 & $20.454^{\star \star *}$ & 0.000 \\
\hline Mimetic & 0.869 & 0.686 & $19.986^{* * *}$ & 0.000 \\
\hline Coercive & 0.786 & 0.920 & $35.967^{\star * *}$ & 0.000 \\
\hline Clan & 0.969 & 0.317 & $4.257^{*}$ & 0.041 \\
\hline Adhocracy & 0.927 & 0.496 & $10.440^{* *}$ & 0.002 \\
\hline Hierarchy & 0.979 & 0.256 & 2.783 & 0.098 \\
\hline Market & 0.991 & 0.169 & 1.217 & 0.272 \\
\hline
\end{tabular}

NOTE: ${ }^{*} \mathrm{p}<.05 ; \quad{ }^{* *} \mathrm{p}<.01 ;{ }^{* * *} \mathrm{p}<.001$

Table 6 shows the results of univariate Ftests. Five of the seven predictor variables, i.e., normative pressures, mimetic pressures, coercive pressures, adhocracy culture, and clan culture, were proved to have significant influence on firms' adoption intention. Thus, the results of the two-group discriminant analysis supported the findings of overall differences between the high adoption group and low adoption group and helped us test our hypotheses.

$\mathrm{H} 1$ to $\mathrm{H} 3$ posited that the greater the firm's perceived institutional pressures (normative pressures, mimetic pressures, coercive pressures), the greater the likelihood that the firm would adopt eSCM. The results of Table 6 supports these hypotheses $(\mathrm{H} 1: \mathrm{F}=20.454$, $p<.001 ; \quad H 2: \quad F=19.956, \quad p<.001 ; \quad H 3$ : $F=29.750, p<.001$ ).

For the organizational culture variables, $\mathrm{H} 4$ suggested that the higher its clan culture, the greater the likelihood that a firm would adopt Internet-enabled SCl. The results of Table 6 provided support for $\mathrm{H} 4$. $\mathrm{H} 5$ noted that the higher its adhocracy culture, the greater the likelihood that a firm would adopt Internetenabled SCl. As Table 6 shows, H5 was supported. $\mathrm{H} 6$ posited that the lower its hierarchy culture, the greater the likelihood that a firm 

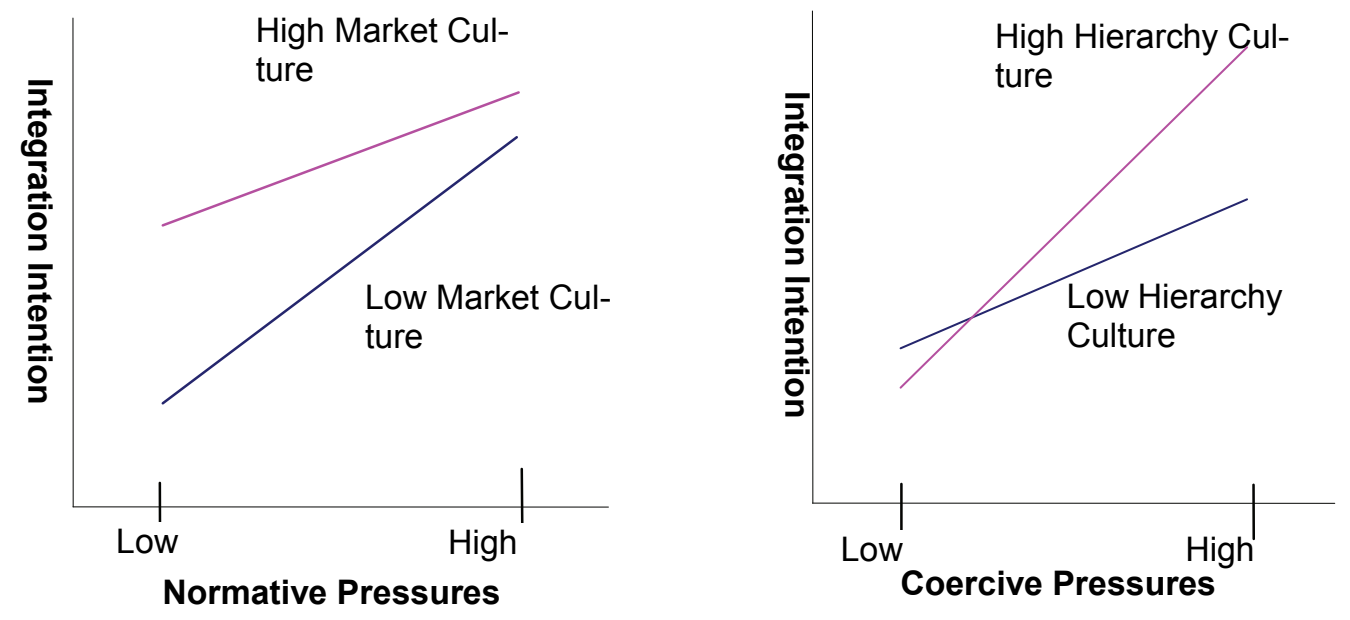

\section{Figure 2 - Interaction Effects}

would adopt Internet-enabled SCl. Yet, the results show that a high hierarchy culture is associated most strongly with the high adoption group. Thus, $\mathrm{H} 6$ was not supported. $\mathrm{H} 7$ suggested that the higher its market culture, the greater the likelihood that a firm would adopt Internet-enabled SCl. The results provide no support for $\mathrm{H} 7$. In summary, the twogroup discriminant analysis of our research provided strong evidence to support that both institutional pressures and organizational culture can predict a firm's intention to adopt Internet-enabled SCl.

\section{Further Analysis}

According to Weick (1995), a firm's organizational culture can strongly affect how environmental pressures are interpreted by the firm's senior executives. Levy and Kolk (2002) further propose that the firm's organizational culture could determine how it responds to institutional pressures. Based on these arguments, different organizational culture may lead to senior executive's different perceptions of institutional pressures, and such different perceptions would then direct firms' market responses differently. In this research, given that hierarchy and market culture cannot impact firms' eSCM adoption intention directly, we did further analysis to test wheth er these cultures can influence such intention indirectly. Thus, we conducted post hoc analysis to find any possible significant interaction effects between institutional pressures and organizational culture.

Given institutional and cultural factors are continuous variables in our research, we followed Aiken and West's (1991) suggestion: "derive procedures for post hoc statistical probing of interactions between continuous variables that closely parallel simple effects testing within the ANOVA framework" (p. 5). Thus, we employed the ANOVA framework to test our data. First, we separated the level of institutional pressures and organizational culture into "high" and "low" groups through mean split. Then, we took firms' eSCM adoption intention as the dependent variable, and conducted the multivariate analysis.

Finally, the ANOVA results identified the interaction effects between coercive pressures and hierarchy culture, $F(2,134)=3.586$, $\mathrm{P}<.05$, and between normative pressures and market culture $F(2,134)=5.472, P<.05$, on firms' eSCM adoption intention. As Figure 2 shown, the effects of coercive pressures (normative pressures) on firms' eSCM adoption intention will be differently depending on hierarchy (market) culture, that is, the influ- 
Adoption of Internet-enabled Supply Chain Integration: Institutional and Cultural Perspectives / Liu et al.

ence is stronger at high levels of hierarchy (market) culture than at low levels. Although no other interaction effects were identified in this study, the finding still supports our hypotheses that there were interaction effects between firms' perceived institutional pressures and their organizational culture. It indicates that the hierarchy (market) culture can indirectly impact firms' intention to adopt eSCM by moderating the effects of coercive (normative) pressures.

\section{Conclusion and Discussion}

\section{Conclusion}

The objectives of this study are to examine the antecedents of Internet-enabled SCI from both institutional and organizational perspectives. Like prior research (e.g., Chi et al., 2007; Grewal and Dharwadkar, 2002; Ke et al., 2009; Teo et al., 2003), the results identify the positive relationships between firms' perceived institutional pressures (i.e., normative, mimetic and coercive pressures) and their intention to adopt eSCM. This finding reveals that institutional pressures can act as the best discriminators for firms' intention on integrating with their channel partners via Internet technologies.

Additionally, in this research, the adhocracy and clan culture are indicated as valid discriminators for firms' intention to adopt eSCM. This finding suggests that senior executives in firms with high adhocracy or clan cultures are more likely to push their firms to adopt Internet-enabled SCl. Moreover, the result also indicates that the adhocracy culture can affect firms' Internet-enabled SCI more effectively than all other cultures (comparing the Wilks' Lambda and significant level in Table $6)$.

Our results do not identify the hierarchy and market culture as significant discriminators for firms' eSCM adoption inclination. Instead we discovered the different roles of the organizational culture's organic and mechanistic process. Specifically, the organic process of organizational culture positively impacts firms' intention to adopt eSCM, but the mechanistic process does not. This finding is consistent with the reports of other researchers (e.g., Detert et al., 2000) which suggest that firms focused on flexibility were more inclined to conduct innovative decisions than those focused on stability. The organic processes make firms more inclined to take risks and push for constant and continuous improvements (Detert et al., 2000). Thus, given the purported benefits of Internet-enabled SCl, firms with high organic processes would be more likely to adopt it.

Finally, we find two interaction effects. One is between coercive pressures and hierarchy culture, the other is between normative pressures and market culture. These findings indicate that the mechanistic processes of organizational culture can enhance the influences of coercive and normative pressures on Internet-enabled SCl. The finding of the organic process's direct influences further identifies the differences between the organic and mechanistic process' role in firms' decision making. Unlike an organic process which focuses on flexible, free-following management, a mechanistic process is focused on control, stability, and order and favors rules and procedures (Deshpandé et al., 1993). Given that complying with institutional pressures can enhance firms' stability, legitimacy and social prestige (DiMaggio and Powell, 1983; Grewal and Dharwadkar, 2002), firms favoring mechanistic process would take such compliance as an efficient strategy and adopt it.

On the other hand, the interaction effects finding also indicates the differences between externally focused and internally focused cultures. Firms normally submit to normative pressures from a long-term strategic perspective (Lawrence et al., 2001). Thus, the identified interaction effects between normative pressures and market culture support the argument that externally focused cultures favor a strategic viewpoint and are concerned with long-term effectiveness (Berthon et al., 2001). Similarly, firms normally adopt a coercive strategy to gain partners' short-term compliances (Antia and Frazier, 2001). Thus, the interaction effects between coercive pressures and hierarchy culture support the view 
that internally focused cultures favor operational decision-making issues and concerns relating to firms' short term organizing issues (Berthon et al., 2001).

\section{Limitations}

Our study has the following limitations that can be addressed by future research. First, this study only includes data from the preadoption period. A longitudinal study may enrich research findings by offering information on the causal relationships among focused variables. A longitudinal study also will reduce the common method bias that undermines the validity of studies that collect data from a single source at a single point of time (Podsakoff et al., 2003), while such bias is not an issue in this study.

Second, we assess Internet-enabled SCl adoption through testing firms' eSCM adoption intention. Although this method is applicable in theoretical and empirical consideration, it still may avoid some parts of Internetenabled $\mathrm{SCl}$ decision, such as human resources and financial issues (Trkman et al., 2007). Thus, future research should develop scales that measure Internet-enabled $\mathrm{SCl}$ comprehensively.

Finally, the demography of our research sample may limit the generalizability of our findings. Given the difficulties in collecting data on inter-organizational issues, we collected data from executives who were from different firms but had obtained training from the same institution. With this choice, we compromise the generalizability of our research. For example, executives with different education or work in other developing or developed economics entities may have different perceptions about Internet-enabled SCI and different values of its potential risks. Such differences may make these executives' decision making process different from those of our research subjects. Therefore, we suggest that future research should be conducted with samples from different contexts.

\section{Theoretical Implications}

From a theoretical perspective, our study contributes to the literature in four ways. First, this research extends the value of the UET in IS research. Unlike prior research testing executives' cognitions and values on the basis of executives' demographic characteristics (Carpenter et al., 2004; Chen and Hambrick, 1995), this research directly studies senior executives' cognitive maps and values by identifying their cognitions about institutional pressures and using organizational culture as a surrogate for their values.

Second, this research provides a syncretic view for firms' IS related decision-making. It combines the effects of market-level and firmlevel factors on Internet-enabled SCl. Although prior research has tested the effects of market-level (e.g., institutional pressures) and firm-level factors (e.g., organizational culture) (e.g., Ke et al., 2009; Khalifa and Davison, 2006; Leisen et al., 2002; Ruppel and Harrington, 2001; Teo et al., 2003), these factors were studied separately. Some even debated market versus firm-level effects (Eisenhardt and Schoonhoven, 1996). In fact, according to Greening and Grey (1994), firms not only submit to conventions prevailing in the market, but also exert discretion by following their own rules and values. Therefore, a syncretic model including both market-level and firm-level factors may shed new light on the current research issue. It helps us test possible interaction effects between the market-level and the firm-level factors.

Third, compared with prior SCI research, our research highlights the institutional factors, not transaction cost or resources utilization. Thus, this research enriches this line of research by examining the effects of social factors. Our findings suggest that firms are not only economically rational entities, but also socially rational entities. They may submit to institutional pressures to sustain their legitimacy. Through the perspective of institutional theories, researchers can recognize the significance of marketing actions with a social dimension (Handelman and Arnold, 1999), and further deepen their understanding of the influences of the macroenvironment on channel structures (Grewal and Dharwadkar, 2002). 
Adoption of Internet-enabled Supply Chain Integration: Institutional and Cultural Perspectives / Liu et al.

Fourth, our study confirms the importance of organizational culture and, we submit that organizational culture as another critical lens for studies on firms' strategic decision making. This research extends our understanding of organizational culture's role in a firm's strategic choices pertaining to its interorganizational relationships. For example, it indicates that firms favoring an adhocracy culture respond to institutional environment not only more actively than firms favoring other cultures in developed countries, e.g., the United States and Europe (Webster, 1994), but also in developing countries, e.g., China. Finally, this research highlights the different roles played by organic and mechanistic process of organizational culture on managers' decision. This suggests that research on organizational culture should clearly identify the different roles played by factors in the cultural process dimension.

\section{Managerial Implications}

This study offers several practical implications for managers. To gain competitive advantages, firms have invested millions of dollars in IT to facilitate SCl. However, a firm cannot develop Internet-enabled SCl or adopt eSCM interdependently. The success of the integration depends on the integration willingness of its supply chain partners and the diffusion of Internet-enabled systems in the institutional field. Therefore, it is critical for managers to motivate their partners to engage in Internet-enabled $\mathrm{SCl}$ in general and eSCM adoption in particular. Our research offers them guidance and knowledge.

First, managers need to reevaluate the role of institutional pressures in promoting their partners' strategic choices. Recognizing norms or rules in the market is very important. Such knowledge can help firms promote strategic choice within the confines of the institutional environment or devise strategies beyond the confines of the environment (Grewal and Dharwadkar, 2002). Meanwhile, due to the high uncertainty involved and the highly unpredictable consequences, realizing the potential benefits of Internet-enabled $\mathrm{SCl}$ in general and eSCM in particular is challenging for managers of potential adopters. Thus, managers could procure more information about competitors which are successful adopters of eSCM to gain potential adopters' interest and confidence. On the other hand, managers should consider the conditions differently when they employ coercive strategies. Although highlighting coercive pressures is an ineffective influence strategy in developed countries (Barley and Kunda, 1992), it may be a successful strategy in developing countries, such as China. Our result identifies the significant effects of coercive pressures on firms' strategic choices.

Second, assessing partners' organizational culture is another efficient way to promote Internet-enabled $\mathrm{SCl}$ in general and eSCM adoption in particular. Firms favoring flexibility and spontaneity, for example, will find it easier to adopt eSCM. The adhocracy and clan culture are the cultures with high degrees of flexibility and spontaneity. Thus, focusing marketing efforts on firms with adhocracy and clan cultures would be more efficient in promoting market-related cooperation such as the adoption of eSCM. This strategy would be especially effective for firms with an adhocracy culture as they have been found to be more easily impacted by institutional factors than firms with other cultures.

Finally, the study findings also suggest that managers should be aware of the interaction effects between market-level factors and firmlevel factors. In particular, highlighting the interaction effects between institutional pressures and organizational culture is an efficient strategy to promote Internet-enabled $\mathrm{SCl}$ via adopting eSCM. For example, through exerting coercive and normative pressures on partners with high mechanistic processes, firms would be easier to promote them to adopt Internet-enabled SCI.

\section{Acknowledgement}

This research is supported by CityU Strategic Research Grant (Project No. 7002347). 


\section{References}

Aiken, L.S., \& West, S.G. (1991). Multiple Regression: Testing and Interpreting Interactions. Newbury Park, CA: Sage.

Antia, K.D., \& Frazier, G.L. (2001). "The severity of contract enforcement in interfirm channel relationships," Journal of Marketing, 65, 67-81.

Argyris, C. (1977). "Double loop learning in organizations," Harvard Business Review, 55, 115-125.

Armstrong, J. S., \& Overton, T. S. (1977). "Estimating Nonresponse Bias in Mail Surveys." Journal of Marketing Research, 14(3), 396-402.

Barley, S.R., \& Kunda, G. (1992). "Design and Devotion: Surges of Rational and Normative Ideologies of Control in Managerial Discourse," Administrative Science Quarterly, 37(3), 363-399.

Barney, J.B. (2007). Gaining and Sustaining Competitive Advantage. Englewood Cliffs, NJ: Prentice Hall.

Berthon, P., Pitt, L.F., \& Ewing, M.T. (2001). "Corollaries of the collective: The influence of organizational culture and memory development on perceived decision-making context," Journal of the Academy of Marketing Science, 29(2), 135-150.

Boyer, K.K., \& Olson, J.R. (2002). "Drivers of Internet purchasing success," Production and Operations Management, 11(4), 480-498.

Brown, A.D., \& Starkey, K. (1994). "The effect of organizational culture on communication and information," Journal of Management Studies, 31, 807-828.

Buenger, V., Daft, R.L., Conlon, E.J., \& Austin, J. (1996). "Competing values in organizations: Contextual influences and structural consequences," Organization Science, 7(5), 557-577.

Burgess, K., \& Singh, P.J. (2006). "A proposed integrated framework for analys- ing supply chains," Supply Chain Management: An International Journal, 11(4), 337-344.

Burt, R.S. (1982). Toward a Structural Theory of Action: Network Models of Social Structure, Perception, and Action. New York: Academic Press.

Campbell, A.J. (1997). "What Affects Expectations of Mutuality in Business Relationships?," Journal of Marketing Theory and Practice, 5(4), 1-11.

Carpenter, M.A., Geletkanycz, M.A., \& Sanders, W.G. (2004). "Upper echelons research revisited: antecedents, elements, and consequences of top management team composition," Journal of Management, 30(6), 749-778.

Chen, M.-j., \& Hambrick, D.C. (1995). "Speed, stealth, and selective attack: how small firms differ from large firms in competitive behavior," Academy of Management Journal, 38(2), 453-482.

Chi, L., Holsapple, C.W., \& Srinivasan, C. (2007). "The linkage between IOS use and competitive action: A competitive dynamics perspective," ISeB(5), 319356.

Choi, T.Y., \& Eboch, K. (1998). "The TQM paradox: relations among TQM practices, plant performance, and customer satisfaction," Journal of Operations Management, 17, 59-75.

Chwelos, P., Benbasat, I., \& Dexter, A.S. (2001). "Research Report: Empirical Test of an EDI Adoption Model," Information Systems Research, 12(3), 304321.

Deshpandé, R., Farley, J.U., \& Webster, F.E. (1993). "Corporate culture, customer orientation, and innovativeness," Journal of Marketing, 57(1), 23-37.

Detert, J.R., Schroeder, R.G., \& Mauriel, J.J. (2000). "A framework for linking culture and improvement initiatives in organiza- 
Adoption of Internet-enabled Supply Chain Integration: Institutional and Cultural Perspectives / Liu et al.

tions," Academy of Management Review, 25(4), 850-863.

Dickson, P. R. (1992). "Toward a GeneralTheory of Competitive Rationality." Journal of Marketing, 56(1), 69-83.

DiMaggio, P., \& Powell, W.W. (1983). "The iron cage revisited: institutional isomorphism and collective rationality in organizational fields," American Sociological Review, 48(2), 147-160.

Eisenhardt, K.M., \& Schoonhoven, C.B. (1996). "Resource based view of strategic alliance formation: strategic and social effects in entrepreneurial firms," Organization Science, 10(2), 136-150.

Finkelstein, S., \& Hambrick, D.C. (1996). Strategic Leadership: Top Executives and Their Effects on Organizations. New York: West.

Frohlich, M.T. (2002). "E-integration in the supply chain: Barriers and performance," Decision Sciences, 33(4), 537556.

Frohlich, M.T., \& Westbrook, R. (2001). "Arcs of integration: An international study of supply chain strategies," Journal of Operations Management, 19, 180-200.

Frohlich, M.T., \& Westbrook, R. (2002). "Demand chain management in manufacturing and services: web-based integration, drivers and performance," Journal of Operations Management, 20, 729745.

Greening, D.W., \& Gray, B. (1994). "Testing a model of organizational response to social and political issues," Academy of Management Journal, 31(3), 467-498.

Grewal, R., \& Dharwadkar, R. (2002). "The role of the institutional environment in marketing channels," Journal of Marketing, 66, 82-97.

Gunasekaran, A., Marri, H.B., McGaughey, R.E., \& Nebhwani, M.D. (2002). "Ecommerce and its impact on operations management," International Journal of Production Economics, 75, 185-197.

Hair, J.F., Anderson, R.E., Tatham, R.L., \& Black, W.C. (1998). Multivariate Data Analysis. New Jersey: Prentice Hall.

Handelman, J.M., \& Arnold, S.J. (1999). "The role of marketing actions with a social dimension: appeals to the institutional environment," Journal of Marketing, 63(3), 33-48.

Howard, L.W. (1998). "Validating the competing values model as a representation of organizational cultures," The International Journal of Organizational Analysis, 6(3), 231-250.

Johnson, J.L. (1999). "Strategic integration in industrial distribution channels: managing the interfirm relationship as a strategic asset," Journal of the Academy of Marketing Science, 27(1), 4-18.

Kandemir, D., Yaprak, A., \& Cavusgil, S.T. (2006). "Alliance Orientation: Conceptualization, Measurement, and Impact on Market Performance," Journal of the Academy of Marketing Science, 34(3), 324-340.

Kappos, A., \& Rivard, S. (2008). "A threeprespective model of culture, information systems, and the development and use," MIS Quarterly, 32(3), 601-634.

Ke, W., Liu, H., Wei, K.K., Gu, J., \& Chen, H. (2009). "How do mediated and nonmediated power affect electronic supply chain management system adoption? The mediating effects of trust and institutional pressures," Decision Support Systems, 46(4), 839-851.

Khalifa, M., \& Davison, R.M. (2006). "SME adoption of IT: the case of electronic trading systems," leee Transactions on Engineering Management, 53(2), 275284.

Khazanchi, S., Lewis, M.W., \& Boyer, K.K. (2007). "Innovation-supportive culture: The impact of organizational values on 
process innovation," Journal of Operations Management, 25(4), 871-884.

Kim, D., Cavusgil, S.T., \& Calantone, R.J. (2006). "Information System Innovations and Supply Chain Management: Channel Relationships and Firm Performance," Journal of Academy of Marketing Science, 34(1), 40-54.

Kim, K. (2000). "On Interfirm Power, Channel Climate, and Solidarity in Industrial Distributor-Supplier Dyads," Journal of the Academy of Marketing Science, 28(3), 388-405.

Lawrence, T.B., Winn, M., \& Jennings, P.D. (2001). "The Temporal Dynamics of Institutionalization," Academy of Management Review, 26(4), 624-644.

Lee, H.L., \& Whang, S. (2004). e-Business and Supply Chain Integration (Vol. 62). New York: Springer.

Leidner, D.E., \& Kayworth, T. (2006). "Review: a review of culture in information systems research: toward a theory of information technology culture conflict," MIS Quarterly, 30(2), 357-399.

Leisen, B., Lilly, B., \& Winsor, R.D. (2002). "The effects of organizational culture and market orientation on the effectiveness of strategic marketing alliance," The Journal of Services Marketing, 16, 201-222.

Levy, D.L., \& Kolk, A. (2002). "Strategic Responses to Global Climate Change: Conflicting Pressures on Multinationals in the Oil Industry," Business and Politics, 4(3), 275-300.

Liu, H., Ke, W., Wei, K.K., Gu, J., \& Chen, H. (2010). "The role of institutional pressures and organizational culture in the firm's intention to adopt Internetenabled supply chain management systems," Journal of Operations Management, In press.

McAfee, R.B., Glassman, M., \& Honeycutt, E.D. (2002). "The effects of culture and human resource management policies on supply chain management strategy," Journal of Business Logistics, 23(1), 118.

McDermott, C.M., \& Stock, G.N. (1999). "Organizational culture and advanced manufacturing technology implementation," Journal of Operations Management, 17(5), 521-533.

Mello, J.E., \& Stank, T.P. (2005). "Linking firm culture and orientation to supply chain success," International Journal of Physical Distribution \& Logistics Management, 35(8), 542-554.

Mentzer, J.T., Minb, S., \& Zacharia, Z.G. (2000). "The nature of interfirm partnering in supply chain management " Journal of Retailing, 76(4), 549-568.

Moore, C.M., Birtwistle, G., \& Burt, S. (2004). "Channel Power, Conflict and Conflict Resolution in Internal Fashion Retailing," European Journal of Marketing, 38(7), 749.

Moorman, C. (1995). "Organizational Market Information Processes: Cultural Antecedents and New Product Outcomes," Journal of Marketing Research, 32(3), 318-335.

Morrison, D.G. (1969). "On the Interpretation of Discriminant Analysis," Journal of Marketing Research, 6, 156-163.

Olson, J.R., \& Boyer, K.K. (2003). "Factors influencing the utilization of Internet purchasing in small organizations," Journal of Operations Management, 21(2), 225-245.

Ottesen, G.G., \& Gronhaug, K. (2002). "Managers' understanding of theoretical concepts: the case of market orientation," European Journal of Marketing, 36(11/12), 1209-1226.

Ouchi, W.G. (1980). "Markets, bureaucracies, and Clans," Administrative Science Quarterly, 25(1), 129-141.

Patnayakuni, R., Seth, N., \& Rai, A. (2006). "In Building social capital with IT and collaboration in supply chains: an em- 
Adoption of Internet-enabled Supply Chain Integration: Institutional and Cultural Perspectives / Liu et al.

pirical investigation," Twenty-Seventh International Conference on Information Systems, Milwaukee, 1435-1456

Podsakoff, P.M., MacKenzie, S.B., Lee, J.Y., \& Podsakoff, N.P. (2003). "Common method biases in behavioral research: A critical review of the literature and recommended remedies," Journal of Applied Psychology, 88(5), 879-903.

Quinn, R.E. (1988). Beyond Rational Management: Mastering the Paradoxes and Competing Demands of High Performance. San Francisco, CA: JosseyBass.

Quinn, R.E., \& Rohrbaugh, J. (1983). "A spatial model of effectiveness criteria: Towards a competing values approach to organizational analysis," Management Science, 29, 363-377.

Rai, A., Patnayakuni, R., \& Seth, N. (2006). "Firm performance impacts of digitally enabled supply chain integration capabilities," MIS Quarterly, 30(2), 225-246.

Rindfleisch, A., \& Moorman, C. (2003). "Interfirm Cooperation and Customer Orientation," Journal of Marketing Research, 40(4), 421-436.

Ruppel, C.P., \& Harrington, S.J. (2001). "Sharing knowledge through intranets: a study of organizational culture and intranet implementation," IEEE Transactions on Professional Communication, 44(1), 37-52.

Scott, R.W. (1995). Institutions and Organizations. Thousand Oaks, California: Sage.

Son, J.-Y., \& Benbasat, I. (2007). "Organizational buyers' adoption and use of B2B electronic marketplaces: efficiency- and legitimacy- oriented perspectives," Journal of Management Information Systems, 24(1), 55-99.

Subramani, M. (2004). "How do suppliers benefit from information technology use in supply chain relationship?" MIS Quarterly, 28(1), 45-74.
Teo, H.H., Wei, K.K., \& Benbasat, I. (2003). "Predicting intention to adopt interorganizational linkages: an institutional perspective," MIS Quarterly, 27(1), 1949.

Trkman, P., Štemberger, M.I., Jaklič, J., \& Groznik, A. (2007). "Process Approach to Supply Chain Integration," Supply Chain Management: An International Journal, 12(2), 116-128.

Vyas, N.M., Shelburn, W.L., \& Rogers, D.C. (1995). "An analysis of strategic alliances: forms, functions, and framework," Journal of Business and Industrial Marketing, 10, 47-60.

Wagner, H.-T., Beimborn, D., Franke, J., \& Weitzel, T. (2006). In IT business alignment and IT usage in operational process: a retail banking case. Paper presented at the Proceedings of the 39th Hawaii International Conference on System Sciences.

Webster, F.E. (1992). "The changing role of marketing in the corporation," Journal of Marketing, 56(4), 1-17.

Webster, F.E. (1994). Market Driven Management: Using the New Marketing Concept to Create a CustomerOriented Company. New York: John Wiley.

Weick, K. (1995). Sensemaking in Organizations. Thousand Oaks: Sage.

White, J.C., Varadarajan, P.R., \& Dacin, P.A. (2003). "Market situation interpretation and response: the role of cognitive style, organizational culture, and information use," Journal of Marketing, 67, 63-79.

Yeung, A.K.O., Brockbank, W., \& Ulrich, D.O. (1991). Organizational Culture and Human Resource Practices: An Empirical Assessment (Vol. 5). Greenwich, CT: JAI Press.

Zammuto, R.F., \& O'Connor, E.J. (1992). "Gaining advanced manufacturing technologies' benefits: the roles of organization design and culture," Acade- 
my of Management Review, 17(4), 701728.

Zhao, X., Huo, B., Flynn, B.B., \& Yeung, J.H.Y. (2008). "The impact of power and relationship commitment on the integration between manufacturers and customers in a supply chain," Journal of Operations Management, 26, 368-388.

Zhu, K., Kraemer, K.L., Gurbaxani, V., \& Xu, S.X. (2006). "Migration to open-

\section{About Authors}

Hefu Liu is an assistant professor in School of Management at University of Science and Technology of China. He earned his PhD degree with the City University of Hong Kong and the University of Science and Technology of China. He has published in Journal of Operations Management, Decision Support Systems, and Journal of Global Information Management, and in the academic conference PACIS and AMCIS. His research focuses on the knowledge management, Ebusiness, supply chain management, and Inter-organizational systems' adoption.

Kwok-Kee Wei is Chair Professor in the Department of Information Systems at the City University of Hong Kong. He obtained his Ph.D. from the University of York and B.S. from Nanyang University. His research focuses on human-computer interaction, innovation adoption and management, electronic commerce, and knowledge management. Dr. Wei has published widely in the information systems field with articles appearing in Management Science, Journal of Management Information Systems, MIS Quarterly, Journal of Operations Management, Information Systems Research, ACM Transactions on Information Systems, ACM Transactions on Computer-Human Interaction, IEEE Transactions on Systems, Man, and Cybernetics, Decision Support Systems, IEEE Transactions on Professional Communication, International Journal of Human-Computer Studies, and European Journal of Information Systems. standard interorganizational systems: Network effects, switching costs, and path dependency," MIS Quarterly, 30(Special issue), 515-539.

Zsidisin, G.A., Melnyk, S.A., \& Ragatz, G.L. (2005). "An institutional theory perspective of business continuity planning for purchasing and supply management," International Journal of Production Research, 43(16), 3401-3420.

Weiling $\mathrm{Ke}$ is an associate professor in Operations and Information Systems at the School of Business in Clarkson University. Her research areas are Enterprise Systems, Open Source Software, and Electronic Commerce. Weiling serves as an Associate Editor for AIS Transactions of Human Computer Interaction. She has published with Journal of Operations Management, Journal of the Association for Information Systems, Personnel Psychology, Communications of the ACM, Decision Support Systems, International Journal of Electronic Commerce and other IS journals

Jibao Gu is an Associate Professor in University of Science and Technology of China, his research mainly focuses on organizational strategy management. He has published with Journal of Operations Management, Decision Support Systems, Journal of Global Information Management, Asia Pacific Journal of Management, Chinese core management journals such as Forecasting, China Soft Science Magazine, and in the academic conferences including PACIS and ECIS.

Huaping Chen is a Professor in Management school at University of Science and Technology of China. His research interests include information strategies, business intelligence and application. 
Adoption of Internet-enabled Supply Chain Integration: Institutional and Cultural Perspectives / Liu et al.

\section{Appendix}

\section{Final Measures and Items ${ }^{a}$}

Institutional Pressures (Teo et al. (2003) and Khalifa and Davison (2006))

\section{Coercive Pressures}

1. Our main customers that matter to us believe that we should use eSCM.

2. We may not retain our important customers without eSCM.

3. Our main suppliers that matter to us believe that we should use eSCM.

4. Our suppliers that are crucial to us hotly wish us to use eSCM.

\section{Normative Pressures}

1. eSCM has been widely adopted by our suppliers currently.

2. eSCM has been widely adopted by our customers currently.

3. eSCM has been widely adopted by our competitors currently.

\section{Mimetic Pressures}

1. Our main competitors that have adopted eSCM benefited greatly.

2. Our main competitors that have adopted eSCM are perceived favorably by customers.

3. Our main competitors that have adopted eSCM are more competitive.

Organizational Culture (Yeung et al. (1991) and Deshpandé et al. (1993))

\section{Clan Culture}

1. Our organization is a very personal place. It is like an extended family. People seem to share a lot of themselves.

2. The glue that holds our organization together is loyalty and tradition. Commitment runs high.

3. Our organization emphasizes human resources. Morale is important.

\section{Adhocracy Culture}

1. Our organization is a very dynamic and entrepreneurial place. People are willing to stick their necks out and take risks.
2. The glue that holds our organization together is commitment to innovation and development. There is an emphasis on being first with products and services.

3. Our organization emphasizes growth through developing new ideas. Generating new products or services is important.

\section{Hierarchy Culture}

1. Our organization is a very formal and structured place. People pay attention to procedures to get things done.

2. The glue that holds our organization together is formal rules and policies. Following rules is important.

3. Our organization emphasizes permanence and stability. Efficiency is important.

\section{Market Culture}

1. Our organization is a very production oriented place. People are concerned with getting the job done.

2. The glue that holds our organization together is an emphasis on tasks and goal accomplishment. A production and achievement orientation is shared.

3. Our organization emphasizes outcomes and achievement. Accomplishing goals is important.

Adoption Intention (Teo et al. (2003) and Khalifa and Davison (2006))

1. I am contemplating to adopt eSCM in a year's time.

2. I am likely to adopt eSCM in a year's time.

3. I am expecting to adopt $\mathrm{SSCM}$ in a year's time.

NOTE: a. All items are measured using 7point Likert-type scales with $1=$ strongly agree and $7=$ strongly disagree. 